\title{
VOLUNTARY NOISE MAPPING FOR SMART CITY
}

\author{
V. Poslončec-Petrić ${ }^{a *}$, V. Vukovićb ${ }^{b}$ S. Frangeša ${ }^{a}$ Ž. Bačića, \\ ${ }^{a}$ Faculty of Geodesy University of Zagreb, 10000 Zagreb, Croatia - (vesna.posloncec, sfranges, zbacic) @geof.hr \\ ${ }^{\mathrm{b}}$ GEO-BIM d.o.o., Starogradska 25, Samobor, Croatia - valentina.vukovic100@gmail.com
}

KEY WORDS: noise map, smart city, crowdsourcing

\begin{abstract}
:
One of the main concept objectives of smart cities is to create a quality living environment that is long-term sustainable and economically justified. In that context, modern cities are aware of the exposure to various forms of physical and non-physical pollution that needs to be remediated, eliminated or reduced. To achieve that it is necessary to quality determine the sources and reasons of each pollution. The most prominent examples of physical pollution that affects the quality of life of citizens in cities are light and noise pollution. Noise pollution or noise, is mostly the consequence of road and rail traffic in cities and it directly affects the health of citizens. Traffic control, reduction of peak congestion, dispersion and traffic redirection or building protective barriers, are ways that cities use to reduce the amount of noise or its effects. To make these measures efficient it is necessary to obtain the information related to the level of noise in certain areas, streets, cities. To achieve this, smart cities use noise mapping.

The city of Zagreb since 2012, participates in the i-SCOPE project (interoperable Smart City services trough Open Platform for urban Ecosystems). i-SCOPE delivers an open platform on top of which it develops, three "smart city" services: optimization of energy consumption through a service for accurate assessment of solar energy potential and energy loss at building level, environmental monitoring through a real-time environmental noise mapping service leveraging citizen's involvement will who act as distributed sensors city-wide measuring noise levels through an application on their mobile phones and improved inclusion and personal mobility of aging and diversely able citizens through an accurate personal routing service. The students of Faculty of Geodesy University of Zagreb, who enrolled in the course Thematic Cartography, were actively involved in the voluntary data acquisition in order to monitor the noise in real time. In this paper are presented the voluntary acquisitioned data of noise level measurement in Zagreb through a mobile application named Noise Tube, which were used as the basis for creating the dynamic noise map.

The paper describes how citizens through voluntarily collected geoinformation can directly influence decision-making in their community, which certainly affects the quality of life.
\end{abstract}

\section{SMART CITY \& SMART PEOPLE}

According to the United Nations data (OUN, 2014), in 1950s only $29 \%$ of the world population resided in urban areas. Today, that percentage increased to $50 \%$, and it is predicted that by $2050,70 \%$ of the population will be residing in urban areas. In Europe, this percentage is higher and amounts to $80 \%$. According to some sources, the city is an area with high population density, where most population works in industry, commerce and services. It is necessary to resolve some infrastructural problems such as energetics, energy efficiency, public lighting, urban water supply and drainage, traffic, and, last but not least - the impact on the environment. But how can a city affect everything that happens, plan, think and finally act? The answer to these questions is the concept of smart cities. A smart city is a place where traditional networks and services are more efficient due to the use of digital and telecommunication technologies, in order to improve the quality of life of its citizens and to make progress with the business sector.

The increasing number of inhabitants in the cities and the development of information and communication technology induced the development of new concepts in city management in order to allow sustainable development. Today's concept of smart cities is a result of the gradual development of knowledge and ideas related to the problems of modern cities. The oldest city concept is digital city that was used to organize city's digital initiatives, for what was later used the term cyber city.
The next stage in the development of the concept were ubiquitous cities (U-cities) which today evolved into the concept of smart cities (Schuurman et al., 2012)

The concept of smart city is linked to the concept of smart or participating citizens, who actively participate in the realization of smart cities, both through participation in decision-making processes and, more specifically, in gathering various information needed to create a base, the starting data sets. The voluntary gathering of information about the area or the state of the area by the citizens (crowdsourcing) represents a significant step forward in the design of control systems and enables the elimination of certain weaknesses of the concept of smart cities (Schuurman et al., 2012).

\section{NOISE \& ENVIRONMENT}

In addition of improving the quality of life of citizens, environmental concerns also need to be considered. The well known statement by Robert Koch in 1905 declared that the day when man will have to fight noise as inexorably as cholera and the plague will certainly come.

Today, noise is defined as any unwanted sound in the environment where people live and work, causing an uncomfortable feeling and can adversely affect health. Sensitivity to noise depends on the characteristics of noise (strength, rhythm, content), individual characteristics of 
exposed person (state of hearing organs, age, individual sensitivity to noise) and also on the length, type and mode of exposure (person's position towards the source of the noise, the presence or absence noise during the holidays taken during working hours and leisure). The main sources of noise in outdoors are traffic (figure 1), constructional and public work, industry, recreation, sport and entertainment. In a closed living space noise sources are service units related to residential building, household machinery and noise from the neighbourhood (Resanović et al., 2011).

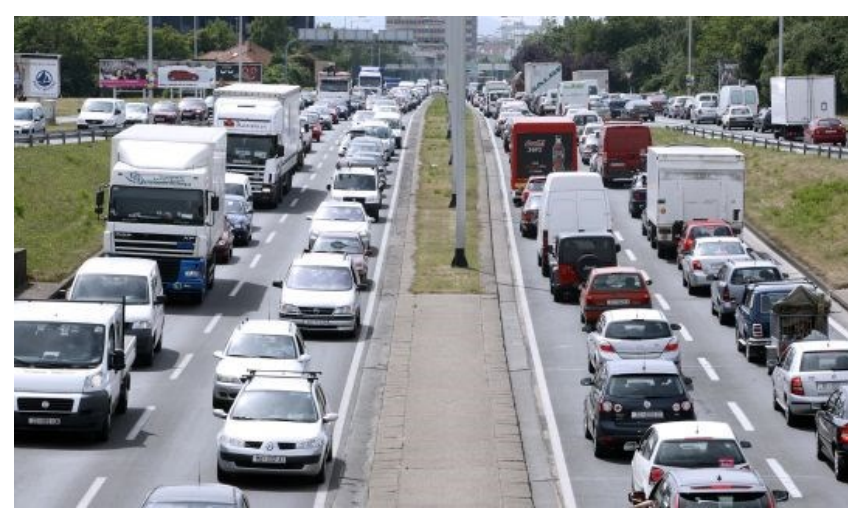

Figure 1. Big noise in Europe (A look on Slavonska avenija main road through Zagreb), (Index.hr, 2009)

As a result of noise increasement caused by urbanization and today's lifestyle, noise and noise pollution is also referred to as modern plague (Goines and Hagler, 2007), given that a significant percentage of the population suffers temporary or permanent effects of exposure to noise. Considering that the sources of noise are product of human activity, it is possible to act on the overall noise reduction. Since the noise pollution is a phenomenon that occurs in the cities, it is logical that its reduction is the subject of interest of the city and city governments, especially in the context of the implementation of the concept of smart cities. In resolving the noise pollution, it is necessary for a smart city to have information about the noise level at locations throughout the city, as well as the sources that generate the noise, which is nowadays conducted through noise mapping.

\subsection{Noise maps}

Noise maps are defined as representations of the current and anticipated level of noise emissions at all sites within the study area, depending on one particular or all sources of noise. Noise control act (NN 20/03) defines the measures to avoid, prevent or reduce harmful effects on human health caused by environmental noise, including noise annoyance - by creating noise maps based on methods for assessing the noise in the environment and developing action plan based on the data used in the preparation of noise maps.

Noise map provides insight into the problems of noise control, and provides a clear, unambiguous and easily readable image of these problems. Apart from this, it provides a more effective spatial planning, noise protection planning of existing areas from noise sources, and the implementation of "acoustic area zoning" in accordance with legally permissible noise levels. Environmental noise management system is set up with the help of strategic noise maps, action plans and conflict noise maps. Strategic noise maps are noise maps that represent an individual source of noise, i.e. road, rail and air traffic, industrial activities including sea and river traffic and the accompanying infrastructure and facilities for sport and recreation, etc.

Act relating to the noise mapping in Croatia is the Ordinance on the method of preparation and content of noise maps and action plans as well as the methods of calculating permissible noise indicators (NN 75/09). According to this act, computational methods for assessment and evaluation of environmental noise are methods from the European Union guidelines on the computation methods for calculating noise in industrial areas, major roads, major railways and major airports. The Act also regulates the preparation and content of strategic noise maps, action plans, and the conflict noise maps.

Strategic noise maps is prepared for the time period 'day', 'night' and 'day-evening-night' (NN 75/09) (Figure 2). A conflict noise map is a difference map noise intended to produce action plans, and action plans are plans designed to manage environmental noise and its harmful effects, including noise protection measures (NN 05/07).

Noise maps are made using a computer with software that analyses and predicts the propagation of sound in a given model. To create a noise map, which accurately describes the current situation it is necessary to obtain data through measurements (Jambrošić 2011).

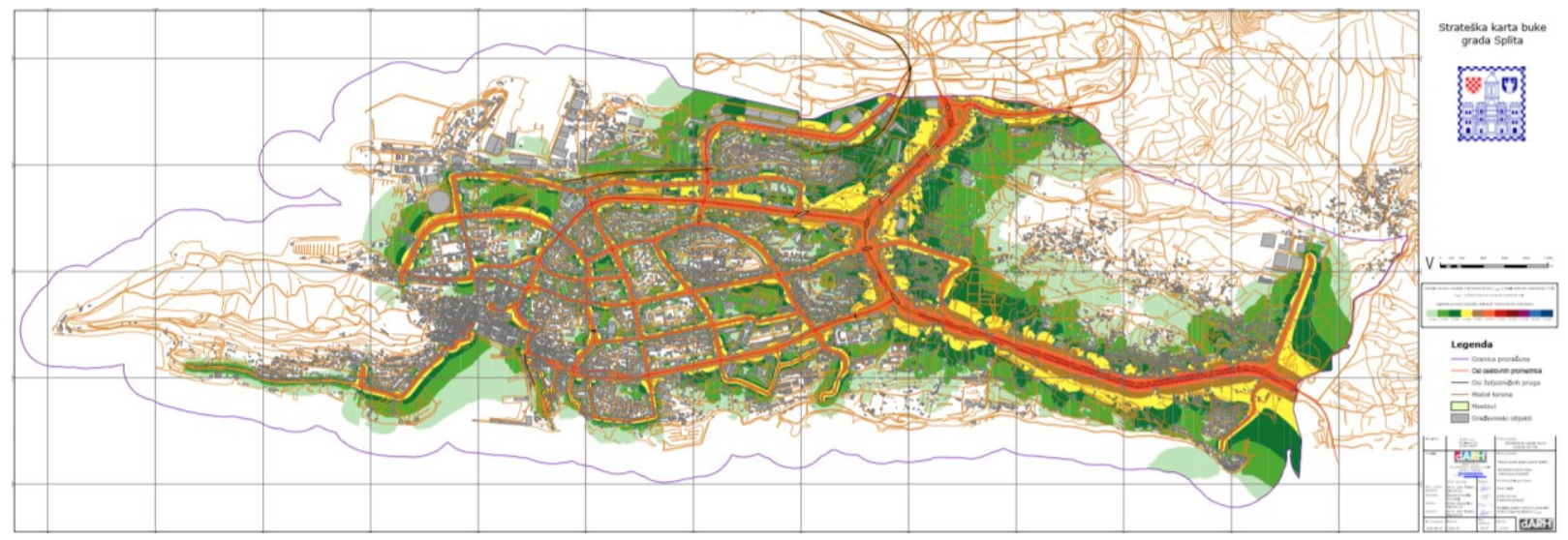

Figure 2. Strategic noise map of road traffic of the city of Split (DARH 2, 2009) 


\section{THE AIM OF CREATING THE DYNAMIC NOISE MAP OF ZAGREB}

One of the projects dealing with the development of technology for smart city services is i-SCOPE project (Interoperable Smart City services through an Open Platform for urban Ecosystems).

\subsection{ISCOPE project}

i-SCOPE project was started in January 2012. It is carried out under the European Commission program ICT-PCP (The Information and Communication Technologies Policy Support Programme).

Objective of the project is to develop and to test technology for smart city services with the use of specially designed web platform based on open 3D Urban Information Model (UIM). The i-Scope project creates an infrastructure that will demonstrate how these models can integrate spatial data from a wide variety of sources to develope tools for analysis, visualisation and stimulation (Ford et al., 2015). The use of 3D model is required when calculating two of the three services developed in the project.

3D UIM is created with the use of geospatial information and it can be used to create „Smart Internet services" based on geometric, semantic, morphological and structural information on city level. Cities can use UIM for improving decisionmaking related to urban planning, city management, environmental protection and energy consumption based on the pattern and morphology, promoting inclusion among different users (e.g. elderly and citizens with different abilities) through services that include the obstacles in the city and through involving citizens in order to obtain georeferenced information related to a particular type of service (i-SCOPE, 2015).

The objectives include the development of three smart city services:

1. optimization of energy consumption through a service for accurate assessment of solar energy loss at building level,

2. environmental monitoring through a real-time environmental noise mapping service involving citizens who act as distributed sensors measuring noise levels through their mobile phones

3. improved inclusion and personal mobility of aging and diversely able citizens through an accurate personal routing service.

Assessment of solar energy potential service is aimed at optimizing energy consumption through accurate assessment of solar potential and energy loss at building level. Application allows calculation of solar potential with high precision, based on accurate $3 \mathrm{D}$ models of urban landscapes. To provide the information on the solar potential at building level, a 3D model of roofs is needed. Energy efficiency at the urban level is estimated through generation of energy emission maps on the basis of aerial thermal camera. The obtained solar atlas allows building owners planning of installation of renewable energy systems such as photovoltaic cells and solar panels, based on the solar potential for every single building (figure 3 ).

Real time noise monitoring service is created by mapping the measured noise levels with the help of the citizens who take on the role of sensors by measuring noise with the use of application on their mobile phones (figure 4) (i-SCOPE, 2015).

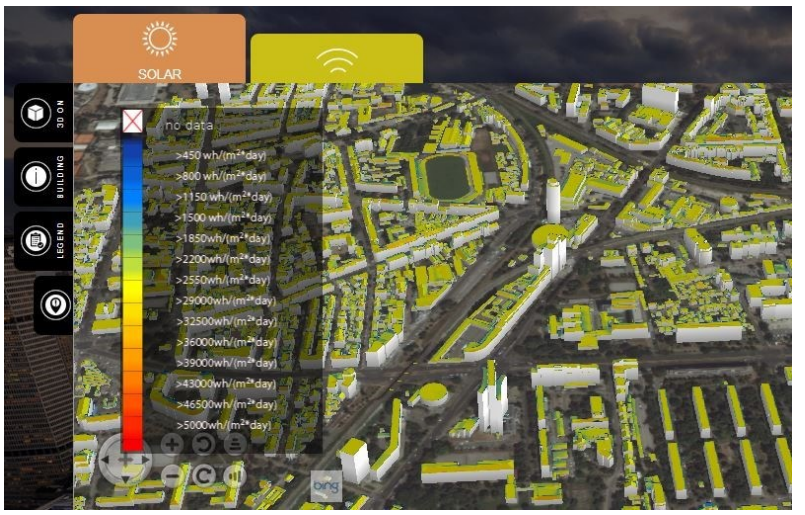

Figure 3. Platform containing available information about solar energy potential at building level

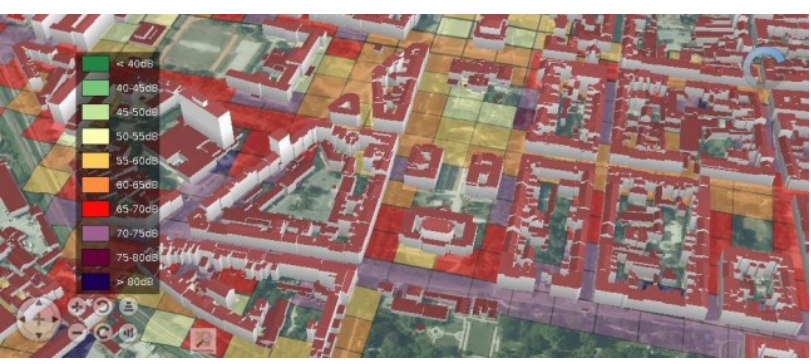

Figure 4. Dynamic noise map on the web platform with a $3 \mathrm{D}$ model

Personal routing service can help elderly users and increase mobility of differently-abled people. The service provides routing and creating routes of movement, while taking into account the detailed data and the characteristics of the urban area, including barriers to movement, information on path slope and other surface characteristics. For these reasons a 3D UIM is needed. These data is used to form the text that describes a specific area or route, suitable for portable or mobile phones adjusted for people with vision disabilities (figure 5).

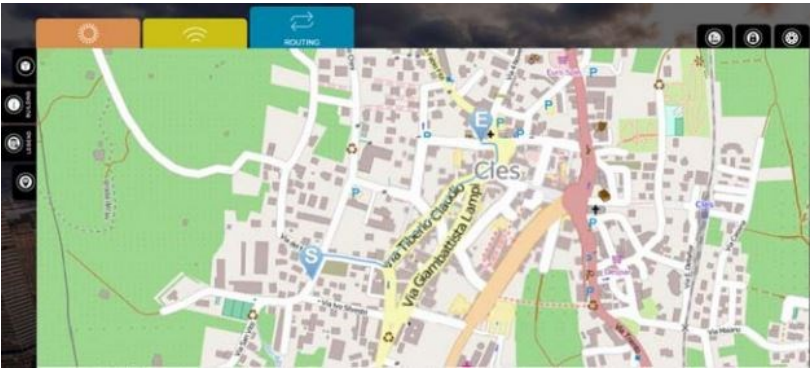

Figure 5. Platform with available information and routes of movement for senior citizens

iSCOPE project includes 9 cities (Zagreb, Zadar, Vienna, Lazio, Indjija, Trident, Malta, Newcastle and Baia Mare). The duration of the project is 36 months (it was completed in July 2015), with the total value of the project of 4.040.000,00 euros. The official web site of the project is: http://iscope.graphitechprojects.com (i-SCOPE, 2015). 


\subsection{NoiseTube application}

For noise measuring with the user's smartphone, in the context of this project, the NoiseTube application was used. Application was developed within the same research project started in 2008 at Sony Computer Science Lab in Paris, and is based on a participatory approach for controlling noise pollution that includes the general public to use their mobile phones to measure noise exposure in everyday surrounding (NoiseTube, 2015). Voluntary approach promotes the project and allows anyone to participate in creating the collective noise map by sharing geolocated measurements with the NoiseTube community.

Before starting the measurement it is necessary to do a simple user registration on www.noisetube.net (figure 6) and after downloading the application adjust settings on the user's smartphone.

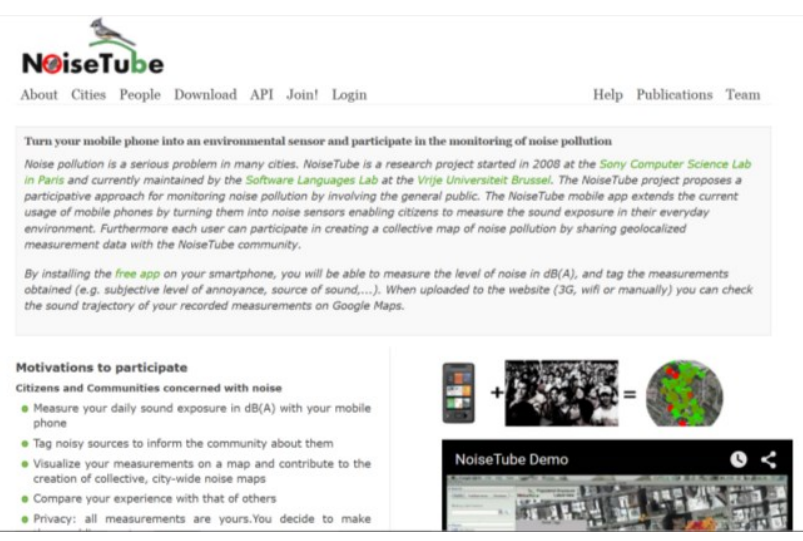

Figure 6. NoiseTube web page

Upon completed measurements, the data can be saved locally or uploaded on NoiseTube server. The processing of the measured noise data usually takes 24 hours or less, and after receiving an email notification, the data can be downloaded in .json of. $\mathrm{kml}$ format (Vuković i dr., 2015a).

\section{DYNAMIC NOISE MAPPING OF THE CITY OF ZAGREB WITH THE USE OF VOLUNTARILY OBTAINED DATA}

One of the services developed as part of the i-SCOPE project is a system for monitoring noise levels in cities, considering that noise is one of the most widespread environmental problems in Europe, with serious consequences on human health. Monitoring of noise is conducted with the help of a mobile phone application that involves citizens who voluntarily acquire noise data in their surroundings. The data allows creating a noise map that gives a realistic image of this important issue in a city such as Zagreb.

Noise map as a basis for acquiring systematized and standardized knowledge on noise pollution in city areas, or as a basis for taking measures to reduce noise pollution generally must meet certain criteria. First of all, the amount of data collected must be adequate or redundant and well distributed throughout the area where measurements were conducted. Data should also be obtained in a specific period of time or continuously collected in a sufficient extent. This requires the city government to use new methods of communication and interaction with citizens to activate citizen engagement.

\subsection{Crowdsourcing}

By definition, crowdsourcing is the act of taking a job traditionally performed by a designated agent (usually an employee) and outsourcing it to an undefined, generally larger group of people in the form of an open call (Howe, 2006). The term was shaped by the journalists Jeff Howe and editor Mark Robinson of Wired magazine in 2006 in an article on the issue, after which it became globally used.

Although the term is most commonly associated with the use od the Internet, it is not a novelty. The best known and globally approved project established on the principle of crowdsourcing is an example of the Oxford dictionaries from 1884, when an open call for volunteers was sent for contribution to indexing of all words in the English language with examples of their use with quotations. Wikipedia itself functions in a similar way, only with the use of the Internet; users who have certain knowledge related to a specific subject are free to contribute to the creation of the global online encyclopaedia. Individuals are not paid for their work, their contribution is exclusively voluntary. OpenStreetMap project, inspired by Wikipedia, allows users to contribute to the creation and editing of world maps. User registration is required and data collected using GPS devices, aerial photogrammetry or other free sources can be shared with the community. That way OpenStreetMap collects, updates and offers free geographic data, such as city maps, to anyone for use and editing.

The appearance and distribution of mobile telephones has taken crowdsourcing to a new level. Nowadays, most people in our everyday surrounding own mobile telephone, mostly smartphone. Smartphones are available at very affordable prices and include many built-in sensors such as camera, GPS receiver, microphone, proximity detecting sensor, compass, accelerometer, gyroscope etc. With the use of sensors, it is possible to obtain a variety of information quickly and easily, and with the development of technology, information will become more precise and diverse. The main motivation for involving users with their devices is the possibility of obtaining a large amount of information that requires the use of sensors.

Motivation is the main problem to be solved with the inclusion of a large group of people to achieve a certain goal. Users can be motivated in different ways: money, personal gain, moral impulses for contribution to the community or some other subjective motivation. The former highly successful collaborative projects mentioned above have shown that is certainly possible to motivate the users to participate without gaining financial benefit.

NoiseTube project relies on motivating users by offering a free smartphones application to usage (which can also be used for personal purposes without sharing information with the community) and every user that is a citizen in a larger city encounters with noise on a daily basis. This way the awareness of this problem increases among the affected citizens, and together they can participate in its resolution (Vuković, 2015). 


\subsection{Voluntary measurements by the students of the Faculty of Geodesy of the University of Zagreb}

The students of Faculty of Geodesy, University of Zagreb, who enrolled in the course of Thematic Cartography, were actively involved in second component of the iScope project, i.e voluntary data acquisition in order to monitor the noise in real time using smartphone application. Upon completed installation of the NoiseTube application, the area in the centre of Zagreb was selected (near Faculty) to perform the measurements and to test the application.

A total of 9 students used their smartphones to perform the measurements during one week. Before measuring the level of noise, each student was required to install the NoiseTube application on their smartphone to turn it into a sound sensor. They also completed a free user registration on the NoiseTube website. Using the installed application and GPS receiver in their phone, the measurements were very easy to collect. The application is simple to install and use.

While measuring, the application shows the level of noise in decibels with a graph. The data registration interval is two seconds.

Measurements were peformed during the day, between 9 a.m. and 7 p.m. in the center of Zagreb. It is recommended that single measurement lasts at least 5 minutes. Average student contributed with around 4000 measurements, which took about 2 to 3 hours to complete. Upon completed measurement, the data is automatically sent to the NoiseTube web site, from where can be downloaded in .kml format, (Keyhole Markup Language - a file format used to display geographic data in an Earth browser such as Google Earth) and used in any .kml file supporting software. The data processing on the web site usually takes a couple of hours before it is available for downloading.

Visualization of the original measurement data is displayed in Google Earth in Figure 7.

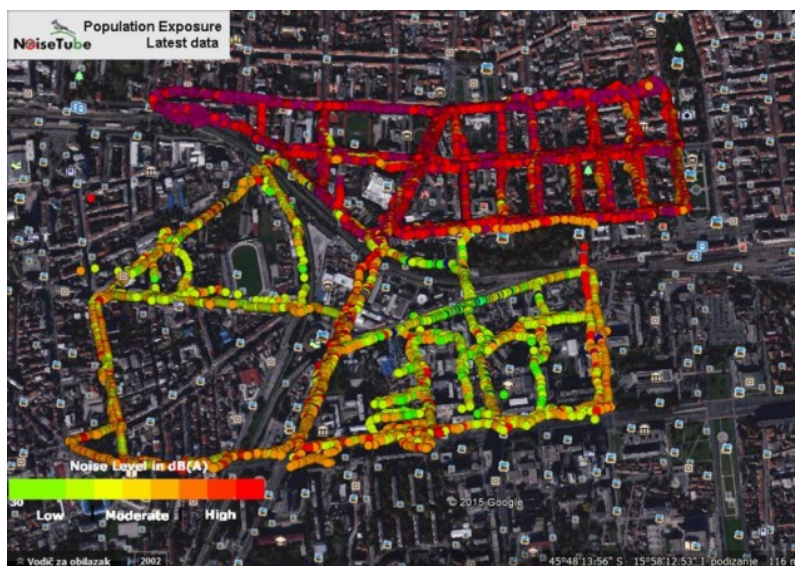

Figure 7. The original measurements displayed in Google Earth (Vuković et al., 2015b)

\subsection{Data processing and analysis}

During the campaign a total of 36993 measurements were conducted in the area of $1400 \times 2800$ meters. The measured noise level is in the range from $35 \mathrm{~dB}$ to $130 \mathrm{~dB}$. It is important to point out that the data refers to overall level of noise present at the time of measuring. That way it is possible to get a very detailed overview of the noise level in the city, and the amount of data that is easily collected by the citizen's gives a fair presentation of the state and pollution in a large, busy and urban city.

Data processing was carried out in QGIS. The data was organized in attribute tables. The areas of measurements were divided in squared areas sized 50 x 50 meters for later computations to be performed and the total area was reduced to $1000 \times 700$ meters to obtain more detailed data for the final results, as the redundancy of the obtained measurements contributes to their reliability. The selected area is in the center of the city of Zagreb. It contains some of the main traffic streets - Savska street, and other, Vodnikova, Jukićeva, Marko Marulić square, Koturaška etc. During the day there is a lot of road and tram traffic on these streets, so the expected noise level is high, since the road traffic is one on the largest noise sources in general. The area also contains parks, yards, playgrounds and botanical garden, where expected noise level is lower.

In order to facilitate the visualization and manipulation of the data, obtained measurements are divided into classes and their corresponding selected colour, depending on the measured level of noise, as shown in Figure 8. To get a better and simpler representation of the obtained data, arithmetic mean for each 50 x 50 area was calculated (Figure 9).

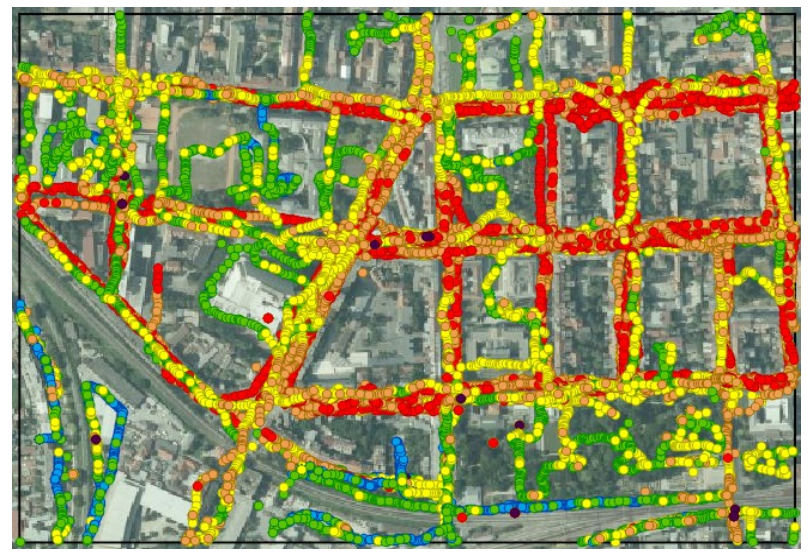

Figure 8. Classified measurements displayed in QGIS (blue and green dots represents lowest noise levels, red and purple the highest) (Vuković, 2015)

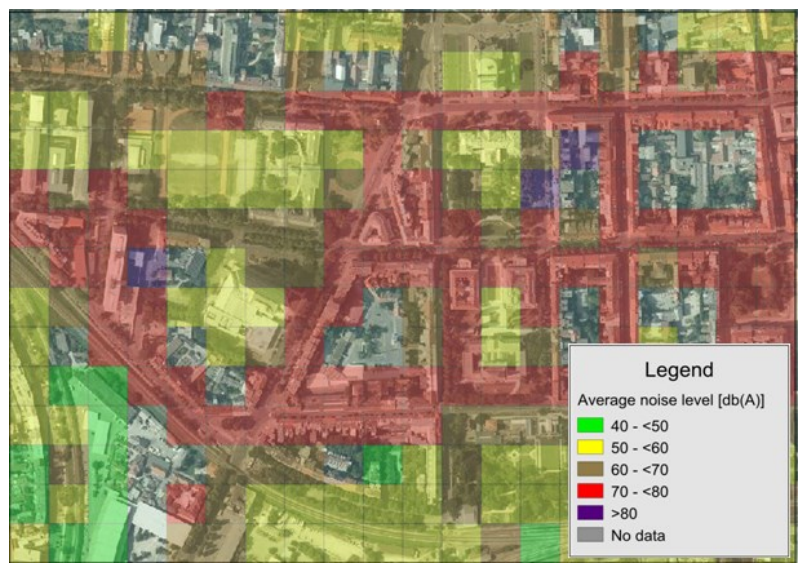

Figure 9. Representation of calculated average noise level displayed in QGIS on digital ortophoto (Vuković, 2015) 
A quick view on the given graphic representation suggests, as expected, rather high noise levels on the selected area. The highest levels of noise were recorded near roads and railways, where the map shows mostly red squares. The average noise level in those areas is between 70 and 80 decibels. Other than road and tram noise, every 5 to 15 minutes the train passes through the area, causing additional noise. Other areas such as playgrounds and gardens show less noise, but being in the close area of traffic, the average noise is around 60 decibels. There is hardly any area with noise less than 50 to 60 decibels, and those areas are shown in green squares. The specific green area where the lowest noise levels were recorded is on the lower left corner of the map in figure 9, is the yard of the Tehnical museum, which is protected from noise with surrounding objects. The map confirms the predictions, and although more additional measurements will probably show a similar result in the final graphical representation, it would surely add weight to its precision and reliability.

\section{CONCLUSION}

Noise map presented in this paper, was created using a free application NoiseTube, a free software QGIS and with the help of students from the Faculty of Geodesy who helped to collect the data while walking the streets of Zagreb. However, to get a representation that gives realistic, total and complete image of a noise problem faced by the residents of a certain city, it would be necessary to give each citizen a device that will measure the levels of noise to which he is exposed, wherever he goes, at any time, regardless of the noise source. That is made possible with the service of noise monitoring in real time through iSCOPE platform and NoiseTube application.

The advantage of a cartographic representation created by participating users is that the map where users contribute, with their constant encouragement to participate, doesn't expires, and over time the number of data increases and it becomes more accurate and complete.

For all projects where community participation is needed, it is very important to motivate the public, and in this case it can be achieved by presenting the obtained data on the amount of noise and noise pollution, for which citizens certainly have interest.

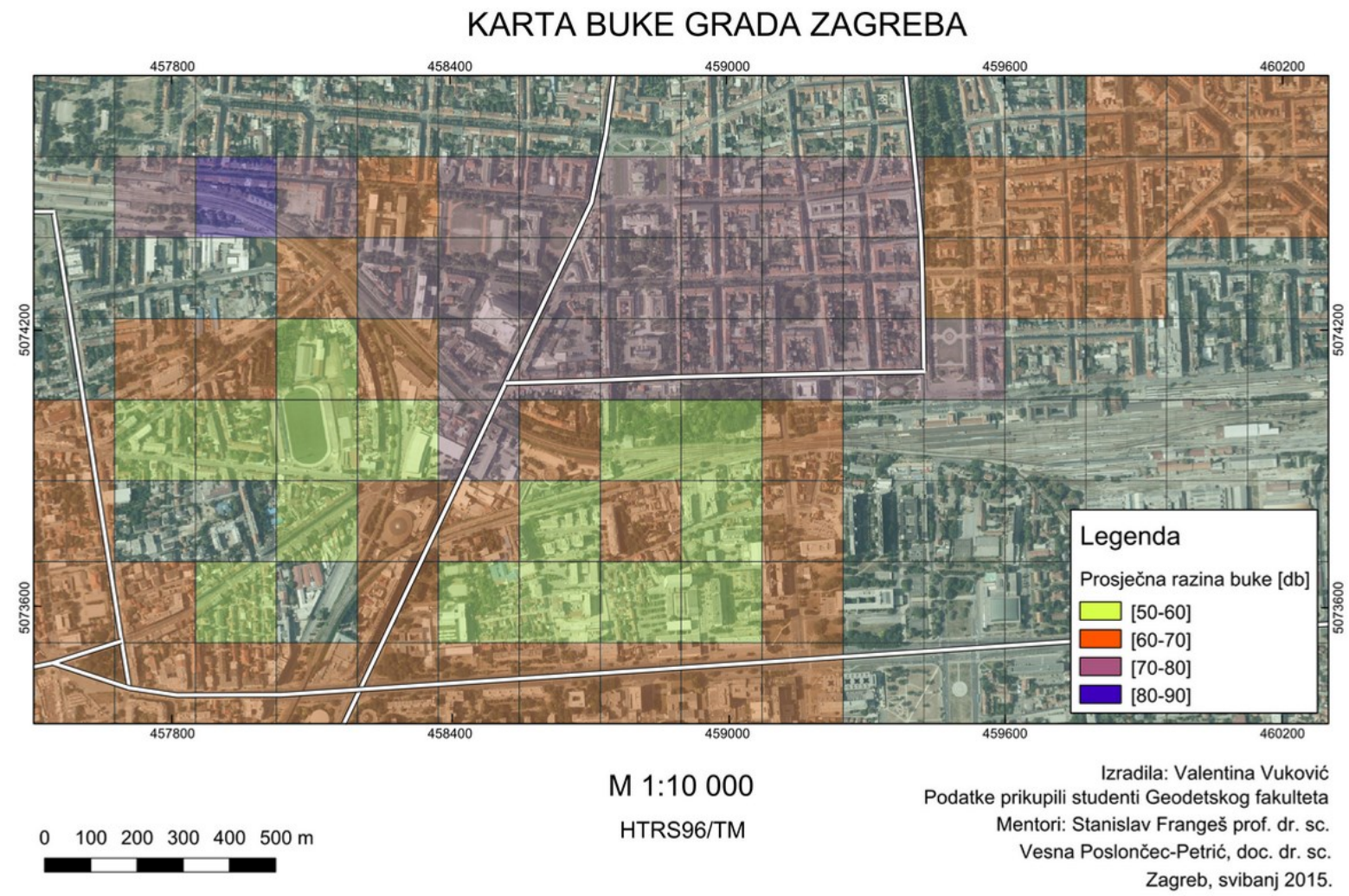

Figure 10. Scaled Noise map of the city of Zagreb created using the voluntarily measured data with the

NoiseTube application (Vuković, 2015)

\section{ACKNOWLEDGEMENTS}

Many thanks to Mrs. Sandra Hamin and Mr. Damir Loncaric from the Office for Energy, Environmental Protection and Sustainable Development of City of Zagreb, for engaging us in this extremely interesting project.
Thanks to the students of the Faculty of Geodesy, University of Zagreb who attended the course of Thematic Cartography during the academic year 2014/2015, who helped during April 2015 to collect noise measurements with their mobile phones. 


\section{REFERENCES}

DARH 2, 2009. Strateška karta buke cestovnog prometa grada Splita, www.split.hr, (05 Oct 2015).

Ford, M., Cadzow, S., Wilson, D., Parslow, P., Prandi, F., Amicis de, R., 2015. Using 3D Urban Information Models to Aid Simulation Analysis and Visualisation of Data for Smart City Web Services (i-SCOPE), http://ceur-ws.org/Vol1322/paper_8.pdf.

Goines, L., Hagler, L., 2007: Noise Pollution: A Modern Plague. Southern Medical Journal 2007; 100(3):287-294.

Howe, J., 2006. Crowdsourcing: Why the power of the crowd is driving the future of business, http://www.crowdsourcing.com, (29 Sep 2015).

index.hr, 2009. Seljačka buna, www.index.hr (10 Oct 2009).

i-SCOPE, 2015. Interoperable Smart City services through an Open Platform for urban Ecosystem, http://iscope.graphitechprojects.com/en/, (29 Sep 2015).

Jambrošić, K., 2011. Zvuk i okoliš, Karte buke, http://www.zmz.hr/download/karte-buke.pdf.

NN 05/07: Pravilnik o načinu izrade i sadržaju karata buke i akcijskih planova, Narodne novine, No. 5, 2007.

NN 20/03: Zakona o zaštiti od buke, Narodne novine, No. 20, 2003.

NoiseTube, 2015. http://noisetube.net/\#\&panel1-1, (05 Oct 2015).

OUN, 2014. World Urbanization Prospects, Organization of United Nations, http://esa.un.org/unpd/wup.

Resanović, B., Vranjković M., Orsag Z., 2011. Buka okoliša javnozdravstveni problem, Hrvatski časopis za javno zdravstvo, Br. 28, Vol. 7, Zagreb.

Schuurman, D., Baccarne, B., De Marez, L., Mechant, P., 2012. Smart Ideas for Smart Cities: Investigating Crowdsourcing for Generating and Selecting Ideas for ICT Innovation in a City Context. Journal of Theoretical and Applied Electronic Commerce Research Vol 7 / Issue 3 / December 2012 / 49-62.

Vuković, V., 2015. Moderne tehnologije u funkciji pametnih gradova - izrada karta buke, Diplomski rad, Geodetski fakultet Sveučilišta u Zagrebu.

Vuković, V., Poslončec-Petrić V., Frangeš S., Hamin S., 2015a. Dinamička karta buke grada Zagreba izrađena u okviru i-Scope projekta, 13. festival znanosti, Zagreb.

Vuković, V., Poslončec-Petrić V., Frangeš S., Hamin S., 2015b: Volontersko prikupljanje podataka u svrhu praćenja buke $\mathrm{u}$ realnom vremenu, 11. savjetovanje Kartografija i geoinformacije, Buzet. 